\title{
THE RIGHT TOOLS FOR THE JOB: \\ THE RIGHT JOB FOR OUR TOOLS
}

\section{Mary Poovey}

\begin{abstract}
This article ponders the questions of why so many literary scholars want to bring literary and economic issues together now, and why it seems so difficult to establish a genuinely cross-disciplinary conversation. ${ }^{1}$ Offering two examples of approaches to the intersection of literary and economic issues that privilege methodology over themes, history, or theory-a very brief genealogy of the concept of a national economy and an equally brief analysis of derivatives-the article calls for an ongoing reflection on whether literary and cultural scholars have the right tools for the job and, conversely, the right job for our tools.
\end{abstract}

KEYWORDS

Literary studies, Methodology, Finance, Economics, National Economy, Derivatives, Interdisciplinarity. 
Ever since the publication of Martha Woodmansee's essay collection in 1999,2 many literary scholars have attempted to bring our work into some relation to economic issues. Some scholars have focused on economic themes in literary textsSilas Marner's obsession with gold in George Eliot's novel, for example, or Shakespeare's depiction of Shylock in The Merchant of Venice. Others have highlighted the finances of publishing-the ways literary production belongs to a larger market society, or the profits that accrued to serial, as opposed to volume, publication in the nineteenth century. Some literary scholars have examined metaphors favored by both imaginative and economic writerscredit, risk, and value come to mind. And still others have explored the extent to which the material media of economic transactionsmoney, bills of exchange, double entry bookkeeping ledgersconstitute forms of writing, which can be read as carefully as literary texts.

To see the big picture, we can group the range of literaryeconomic investigations into several categories. I find it most useful to think in terms of thematic, historical, and theoretical approaches. This taxonomy, however, doesn't say much about why so many literary scholars want to bring literary and economic issues together now, much less why it seems so difficult to establish a genuinely cross-disciplinary conversation (in which economists, not just other literary scholars, also participate). In this article, I want to begin with these fundamental questions: why is it so important now? Why is it so hard? Then, I will provide two examples of approaches to the intersection of literary and economic issues that privilege methodology over themes, history, or theory. What I can't do-alas-is lure economists to the table. At the end of the article, I will suggest why the conversation between literary critics and economists may remain an elusive goal: the tools our respective disciplines have developed not only address different questions; they are also devised to meet different ends.

To address my first question-why do literary scholars want to address economic issues now-I'll offer a sociological answer. In terms of the sociology of disciplines-the degree of relative social authority accorded various academic disciplines-the decades since the 1960s have witnessed two different trajectories for literary study and economic analysis. According to Michael Bernstein's study of the economics profession, academic economists enjoyed relatively little prestige before the $1960 \mathrm{s.}^{3}$ Policy-makers rarely consulted economists, and economists themselves remained deeply divided on basic matters like 
methodology and whether-or to what extent-economists' political commitments should inform their theories. In the United States, this situation had begun to change in the late 1940s with the creation of the Council of Economic Advisors, but the first two decades of this presidential advisory body were characterized by infighting among the advising economists and repeated charges that the economists' supposedly objective recommendations were examples of thinly disguised ideological advocacy. As increasing numbers of academic economists began to embrace mathematical modeling in the 1960s and 1970s, however, dissent within their ranks was gradually replaced by a methodological consensus that pitted the majority of economists against a "heterodox" fringe. This had the predictable effect of enabling economists to present their theories, methods, and practices as a united front, even though squabbles among academics continued behind the scenes. Meanwhile, in governments across Europe and the US, economists also gained credibility and prestige. Governmentemployed economists enhanced the reputation of their discipline through at least two routes: first, they created data-rich models that helped legislators repair war-ravaged economies after World War II (Jan Tinbergen, working in the Netherlands, comes to mind, as do Wassily Leontief, the Russian who developed inputoutput models for the US economy, and John Maynard Keynes, the great British economist, who addressed the problem of Germany reparations); and second, particularly in the United States, the economists chosen to advise the President promoted politically popular growth models over the controversial cyclical models previous members of the Council of Economic Advisors had favored. Growth models in their modern form were introduced in 1962 by John F. Kennedy's Council of Economic Advisors. These models provided quantitative targets for the economy (so that success was easily defined in measurable terms); they advocated flexibility in tax policy (so that taxation could be shifted as political winds changed); they replaced the idea that unemployment is a structural problem with an argument about low aggregate demand (so that attention was redirected toward consumer demand); and they focused on the supply side of the economy (which, once more, enabled legislators to promote productivity and growth rather than inequality or stability). The policies that followed the theoretical shift from cyclical models and sustainability to growth models and supply side economics directed monies to technology, including space travel and, eventually, IT technologies; and they reduced corporate 
taxation in the name of free enterprise and trickle-down theories that claimed that the distribution of wealth was a natural effect of enriching the wealthy. Many of the policies that helped neoliberalism gain a foothold after the creation of the Mont Pelerin Society in 1947 were supported by (and used to support) the growth models mainstream economists embraced from the 1960s on. Thus, while skeptics have raised probing questions about whether economists as a group merit the authority they now exerciseespecially in the wake of the 2008 global financial crisis ${ }^{4}-$ few observers of today's disciplinary hierarchy would dispute that the "Queen of the Social Sciences" reigns supreme in universities and national capitals alike.

The sociological history of literary study has followed a different trajectory since the 1960s (and here my remarks have to be limited to the US.) Academic literary study had received a boost in the immediate aftermath of World War II, when soldiers returning to the US swelled the student numbers in colleges and universities; while the availability of textbooks designed to systematize the study of literature, such as Cleanth Brooks' and Robert Penn Warren's Understanding Poetry (1938) and Understanding Fiction (1943), simplified literary analysis and made majoring in English more attractive. The visibility of the discipline was further enhanced in the late 1960s and 1970s when American literary scholars began to embrace Continental theories about how language creates meaning. Writings by Ferdinand de Saussure, Michel Foucault, Jacques Derrida, and Julia Kristeva led some American literary theorists to push the more reader-friendly methods of New Criticism aside; mainstream newspapers like the Washington Post and the New York Times began to cover the Modern Language Association's annual meetings; and students eager for a practice that was rigorous, theoretically informed, and ostensibly engaged in (pseudo) political discourse filled literature classrooms in the 1980s and '90s. From Derrida's first lecture in the United States-in 1968 at Johns Hopkins University-through the end of the twentieth century, the percentage of English majors within student populations increased in most 4-year universities and liberal arts colleges. While it is notoriously difficult to measure social prestige, on the campuses where I taught during those decades-Yale, Swarthmore College, Rutgers University, Johns Hopkins, and New York University-students of literary theory in particular were lords of the manor-at least among humanities majors. Arguably, they held their own with social science majors as well. 
And then the tide turned. Not all literary scholars were happy with the influx of Continental theory, and, during the very decades in which the economists reached methodological consensus, the rift between Literary Theorists and Custodians of Literature widened as methodologies proliferated and the canon was expanded. What began as a difference of opinion about how literary works should be read (closely and with appreciation, deconstructively and with suspicion, as historical actors, as complicit with dominant ideologies) gradually morphed into disagreements about what teachers of literature should do. Should we teach students to love literature? Should we teach them to be critical readers? Should we expand the canon so that writings by underrepresented populations were included? Should we encourage students to resist the patriarchy? With such battles dividing departments of literary study, and in a global context transformed by the effects of digitalization, a widening gap between the wealthy $1 \%$ and everyone else, and a job market disrupted by assaults on numerous professions, university students understandably turned toward disciplines that seemed more obviously aligned with economic possibilities. In many universities, the numbers of English majors shrank, entire humanities departments were eliminated or consolidated (departments of foreign language, Classics), and university administrators began to reward departments that adopted practices typically associated with the market economy: research assessment exercises that measured faculty performance by pages published rather than the quality of the scholarship (much less teaching); and time-to-degree measures agnostic about the quality of a student's work. With the number of literary tuition-paying majors shrinking and an increase in quantitative incentives to produce faster, many scholars of literature eager to restore our discipline's prestige have hoped to capitalize-however indirectly-on the status economists enjoy. Teaming up with an economist on research projects that link the two disciplines is one way of demonstrating that literary study can play nicely with the market boys. If that isn't practical, then taking up economic themes may be the next best thing.

Of course, there are other reasons for literary scholars to address economic issues in our work. For one thing, we might have something to add to the way economists currently define valuethat is, in purely quantitative terms. In light of most economists' indifference to social issues such as income inequality, gender discrimination, racial prejudice, and climate change, students of literature might offer insights that would otherwise not be 
available. The possibility that literary scholars might have something to add to conversations about issues economists typically monopolize leads to my second question: why is it so difficult for literary scholars to address economic issues in a way that would encourage economists to read our work? The short answer, as you will already have guessed, is that members of the two disciplines speak different languages. Literary scholars use some combination of close and "distant" reading, historical or contextual placement of texts, and theoretical templates to generate new "readings" or interpretations of literary or cultural artifacts. Economists use mathematical models to simulate some (but not all) of the countless variables visible in economic processes and relations. As some economists (such as Dani Rodrik) have pointed out, mathematical models are also, in some sense, interpretations, but they can be presented more easily as "objective" treatments because they rely on the language of mathematics. Even historical analysis, which might seem like an approach common to literature and economics, is suspect to most economists because they consider their discipline to be more like a natural science-physics is the most common analogue-than a study of conditions that can change over time. If you believe, as many economists do, that you are measuring and modeling natural forces, such as supply and demand, that have determinate relations with each other, you won't see your enterprise as a historically contingent inquiry. Nor will the history of your discipline be very interesting except as a litany of approaches that fell short of true science.

Of course, some economists do share the interests of literary scholars: Deidre McCloskey, for example, has long highlighted the roles played in economic analysis by metaphor; and Thomas Picketty's Capital in the Twenty-First Century contains many references to familiar literary texts. These are exceptions, however. Pick up any graduate textbook in economics or finance currently in use at a major university and you will encounter diagrams, equations, and densely composed theoretical treatments of topics like the use of stochastic equations to price assets, or linear constrained optimization, or optimization under uncertainty. For a literary scholar, these texts are very difficult to read, and, even if you have the mathematical training and can master the vocabulary, it's almost impossible to develop an independent idea about the claims they make. These textbooks offer a set of tools to be mastered, not a conversation that is open to engagement. 
Even if literary studies and economics do not share a language or a set of methodological tools, like all disciplines, they do share a reliance on tools that have both theoretical and methodological implications. One way literary scholars might go beyond addressing economic themes in literary texts is to use our tools to investigate economic issues and the claims economists make (both about their discipline and about economies more generally). I turn now to two examples of how tools developed for literary analysis might illuminate important economic issues-albeit not in ways all economists would accept.

The tools best suited to this job seem to me to be the genealogical analysis popularized by Michel Foucault and deconstruction as it has been expanded to interrogate cultural phenomena rather than simply literary tropes. What these two methods have in common is an ability to highlight the constructedness of phenomena that seem, at first glance, simply to be natural objects. Foucault tended to use history to reveal the work of cultural construction-madness and sexuality have histories that allow us to see the role societies have played in making them what they seem naturally to be. Deconstructive analysts tend to rely on identifying contradictions internal to the syntactic field that makes the object meaningful; these contradictions reveal the work necessary to preserve the impression of coherence, and they highlight the performative potential of semantic fields that seem simply to be meaningful. Thus, for example, if one can show that the meanings attributed to Hamlet rest on the metaphor of meaninglessness, then one can argue that a vacuum generates the character who passes as a person. Or, to use a real-world example, if one repeatedly presents an individual as a self-made billionaire, as Donald Trump did in the 1980s, he may create the conditions in which he will be able to actually make large amounts of money, as Trump did with his popular television show, The Apprentice, which ran on US television for fifteen years. Both genealogy and deconstruction enable us to see the social and semantic work necessary to create the appearance of inherent or natural meaning. Because economists present their own objects of analysis as natural forces and their analyses as objective measures of those forces, applying our tools to their work allows us to reveal how economists create and maintain the appearance of nature-how, for example, they have created and maintained central concepts such as the "national economy" or the superiority of economic "growth" over stability or wealth equality. This, in turn, allows us to identify the limitations (and advantages) of economists' use of models, 
for models can do what literary critical tools cannot do: they can abstract and generalize.

I'm now going to provide a very brief genealogy of the concept of a national economy, which is often encapsulated by a single number-the Gross Domestic Product, or GDP. Then, using deconstruction, I'm going to provide an equally brief analysis of derivatives, a financial instrument in which trillions of dollars' worth of value change hands every day. If you want a more detailed discussion of the creation of national economies, please read chapter 6 of Finance in America: An Unfinished Story, the book I published in 2017. If you want a more granular discussion of derivatives, see Finance in America, chapters 9 and 10 or Financial Derivatives and the Globalization of Risk by Edward LiPuma and Benjamin Lee. My remarks are intended to invite you into these topics rather than to convey the complexities of our arguments.

When the Great Depression rocked the global economy in 1929, economists had no tools with which to assess or measure the well-being of a nation's economy. Even though rulers had long depicted the "balance of trade" as a proxy for national health, they had no way to make trade imbalances visible; indeed, no reliable statistics of national production and consumption existed before the 1920s, so it would have been impossible to quantify any nation's economic productivity, much less to present the picture of an international balance of trade. A few countries began to gather such statistics in the 1920s, but it was not until the 1930s that economists were able to depict a national economy as a statistical, sectored, calculable entity that could be reduced to a single number: the GDP.

As is true with many fundamental concepts of modern economics, the "national economy" was forged at the intersection of war and taxation. On the one side, for the US, Great Britain, and Germany, the ravages of World War I pushed governments to quantify their assets: for the victorious Allies, this pressure was increased by the domestic problem of oversupply-a problem exacerbated by the onset of the Great Depression in 1929; and for Germany, the pressure emanated from the US-led Dawes Committee's decision to peg reparations to Germany's national prosperity-that is, its national income. In the US and Great Britain, efforts to collect statistics for national income and productivity were launched by teams headed by Simon Kuznets and Colin Clark under their governments' direction; and in Germany, the Institute for Business Cycle Research, directed by Ernst Wagemann, began trying to update the crude estimates that 
thus far passed as national figures. In the US, the first national income report appeared in 1933 and what became the definitive model for subsequent reports-the National Income Production Account (NIPA)-was first published in 1947. This model was improved by the addition of income-output accounts in the $1950 \mathrm{~s}$ and by flow of funds accounts, which were added in the 1960s. In 1953, the United Nations adopted the amended NIPA (now the System of National Accounts) as the international standard for national income accounts. On the other side of this construct, taxation mattered because, for the Allied nations, knowing how much revenue governments could expect dictated how they could budget for rebuilding and then for a second world-wide conflict; and for the Germans, who had to borrow from the US to pay the demanded reparations, taxation (along with deflation) became the burden its citizenry had to bear to mitigate their collective shame.

In the process of their creation, every stage and facet of these accounting methods provoked fierce debate. In the US, the first set of national estimates were net estimates (which subtracted depreciation, ongoing expenses, and taxes) and they divided the national economy into three domestic sectors (households, corporations, and government) along with a fourth ("rest of the world"). These estimates depicted the economy as a circular flow, and they assigned monetary values to the components of these flows at the points where income or commodities intersected with consumers. Here is Simon Kuznets's attempt to cut through competing theories about how best to measure and value the flows of an economy: "In current reality, the most clear-cut, general concept of national income is income received by individuals; and ... the uninterrupted flow of commodities and services through the economic system is best arrested for the purposes of analysis and measurement at the point when the system reaches the living individual, after it leaves the productive units proper and before it has been diverted into the various channels of consumption.”5 When the US Congress asked Milton Gilbert, one of Kuznets's assistants, to revise the latter's accounting estimates in 1941, as America contemplated entering World War II, Gilbert rejected nearly every working premise that had informed his colleague's work. In 1941, Gilbert was guided not by the problem of oversupply, which was the issue Kuznets had to address, but the question of whether the US could redirect production from domestic consumption to military spending without fueling inflation. In that year, President Franklin Delano Roosevelt had drawn up a war budget that represented half the 
nation's output, and he needed to sell his plan to lawmakers and a population skeptical about whether the nation could afford to go to war. Gilbert shifted the emphasis of his estimates from Kuznets's net measures to gross measurements, and he estimated national aggregates by aggregate expenditure, not individuals' consumption. Gilbert argued that gross aggregates provided a more appropriate measure for the short-term analysis of war spending because some of what net figures subtracted-such as business expenses-were actually available to the government to help finance the war. Gilbert also decided not to count the interest paid on government debt as part of the nation's income because he argued that government debt, which (at that point) was being incurred primarily to finance the war, was not analogous to the interest corporations paid on their outstanding bonds, which constituted a regular cost of doing business. And finally, Gilbert imposed on Kuznets's circular picture of the national economy a static organizing structure borrowed from corporate accounting: the scaffolding of double-entry bookkeeping. This converted the circular flow into a system of inter-related accounts, governed by a set of rules known as accounting identities. This, in turn, made it easier for the accountant to estimate-or imputenumerical values for some factors that were not priced by market transactions-such as national saving or the government deficit. As a result of Gilbert's reorganization of the national estimates, Roosevelt was able to argue that the US economy could support its war effort, inflation would not rise, and the US could lead the world in creating a reliable measure of national productivity, just as it was leading the campaign against Nazi Germany.

While Kuznets and Gilbert vehemently disagreed about the details of national accounting, they saw eye to eye on the importance of this enterprise. Neither of these accounting pioneers, however, acknowledged two related features of the picture of the national economy their work created. First, the sectors into which both accounting systems divided a nation's economy are fundamentally incommensurate. Unlike households, corporations, and even the "rest of the world," governments are not profit-making enterprises. Thus, to apply an accounting system devised for the profit-driven corporation to a government requires the accountant to treat national income as corporate revenue, government consumption as company costs, and the nation's capital formation as profit. Second, and as an extension of this incommensurability, equating national growth with the growth of a corporation meant equating the nation's well-being with 
growth-and, more pointedly, with the growth of the government. Going forward, and as an unanticipated effect of the way the national accounting system is set up, some economists began to argue that the growth of government (its expenditures and costs) is a proxy for the growth of the nation itself. This argument, in turn, helped support the dramatic increase in taxation that Americans saw beginning in 1938, for, in order to grow, a government must have revenue. Guided by some of the same principles that informed the accounting procedures used to measure the nation's economy, successive US tax plans in the 1940s supported the growth of the federal government by beginning to tax not just wealthy individuals but every US citizen and by collecting taxes from working Americans through payroll withholding rather than once a year. Increasing the percentage of American taxpayers from $12 \%$, as it had been in 1930 , to $90 \%$, as it was in 1945 , increased the revenue and power of the federal government; and payroll withholding allowed the government to calculate its tax revenue in advance, budget for future expenditures, and augment its own-and the nation's-present and future power.

This literary-critical genealogy of national accounts reveals the historically contingent nature of part of the economic fact-making apparatus we now take for granted. Pursued in more detail, it could also show how national accounting was naturalized-the social process by which national accounting shed the arguments that punctuated its history, lost its historical contingency, and came to be taken-for-granted. The tool I now apply to an economic object focuses not on history but on the structure of a financial instrument. My literary-critical tool is deconstruction, and the economic object is that array of financial assets called derivatives.

A derivative is a contract between two parties whose value derives from an underlying asset. Derivatives trading allows investment banks, sovereign states, and large-volume traders to hedge their risks, as farmers have long been able to do in commodities futures markets. Instead of hedging against future changes in price, however, as farmers do when they draw up futures contracts on their crops, investors use derivatives to hedge the risk associated with the ownership of financial assets, such as foreign currencies or specified interest rates-whatever underlying asset the contract names. In their most exotic form, such as credit default swaps, financial derivatives can even allow the trader to separate risk from the underlying asset and trade that risk in a separate contract. 
As a literary theorist, I can see that the structure of a derivativethe contract and its underlying asset-replicates the structure of the linguistic signifier, as Ferdinand de Saussure described it in the early twentieth century. In de Saussure's account, the signifierthe word-is separated from what gives it value-its underlying signified or meaning. This insight ushered in semiotics, structuralism, and deconstruction later in the twentieth century as explorations of the ways language generates, but fails to stabilize, meaning. That language generates the possibility of meanings in excess of the words on the page has allowed generations of literary scholars to find new value in texts that have been read millions of times. This limitless value is, in a very real sense, the currency of literary study: it is what literary scholars have to offer our students; it adds immeasurable value to life; the value of the literary experience is inexhaustible and incalculable.

Like the linguistic signifier, the financial derivative generates value in excess of the originating contract, and, also like the signifier, financial derivatives create value from the gap between the contract and the underlying asset. In the case of the financial derivative, however, the value created is not incalculable. Simple derivatives, such as futures, forwards, swaps, and options, specify a current price and a future price for the underlying asset. The purchaser of the contract can agree to sell, buy, or exchange the underlying asset at this price at a specified time in the future; the inherent risk is that the future price will depart from the value named in the contract. It is this element of risk that both enhances the potential monetary value of financial derivatives and can make them dangerous-not only to the two contracting parties, but to the global financial system as a whole. To see how this danger spread throughout the global financial system in the decades between 1980 and 2008, we need a brief history of financial derivatives.

The financial model and physical institution that allowed traders to price and exchange financial derivatives were products of the early 1970s. In 1972, Fisher Black, Myron Scholes, and Michael C. Jensen published a paper explaining their options pricing model; that same year, the Chicago Mercantile Exchange International Money Market opened for trades on currency futures (IMM). ${ }^{6}$ The historical context for the first of these developments was the probabilistic revolution that had transformed the academic understanding of finance in the 1960s; in this revolution, financial theorists began to apply stochastic process techniques (such as stochastic calculus) to price financial assets. The historical context for the IMM was President Nixon's abnegation of the Bretton 
Woods Agreement in 1971; as the value of national currencies began to float instead of being tied to gold, it became possible for traders to speculate in currency futures and exchange rates. In the next three decades, a revolution in information transmission (the digital revolution)-which made real-time international conferencing and near-instantaneous data transmission and trading possible-transformed securities trading and linked national financial markets in a single global system. Add to this the deregulation of financial markets, which began in 1980, the growth of a shadow banking system, which also accelerated after 1980, and the passage, in 2000, of the US Commodities Futures Modernization Act, and you have the ingredients for an explosion in the numbers and kinds of financial derivatives products: credit-linked notes, credit default swaps, collateralized debt obligations, and collateralized debt obligations squared, to name just a few. Many of these financial products are synthetic, in the sense that they require no underlying physical asset at all; some (structured investment vehicles) are typically not recorded on the balance sheet of the entity that originates them; and all are traded in the so-called shadow banking system, that network of financial institutions that perform the core bank-intermediation functions outside the regulated system of official banking. These institutions, which are not protected by government insurance and which tend to be global, rather than national, in reach, include hedge funds, money market funds, finance companies, and security broker-dealers who fund their assets with repurchase agreements. The monetary value of the financial derivatives traded through this network is literally incalculable-not, as with literary texts, because we have no metric by which to quantify their worth but because the financial records necessary to do so are not routinely made public. The best figures I can come up with suggest the magnitude of these assets: in 2008, the value of worldwide credit derivatives alone was estimated at \$62 trillion, and in 2011, the worldwide value of outstanding contracts in interest rate derivates was estimated at \$500 trillion.

In 2008, the global house of cards erected with these financial derivatives came crashing down, and we are still living with the fallout of that collapse. One could explain the collapse, as my co-author and I do in Finance in America, by pointing to the maturity mismatch in the shadow banking system: too many unregulated financial institutions financed long-term illiquid assets with short-term liabilities; and when Americans began to default on unaffordable mortgage loans, which constituted 
the bulk of the long-term illiquid assets, the weak points in the global financial system gave way (Bear Sterns, Lehman Brothers, AIG, the national economy of Iceland). Or one could explain the collapse by saying that engineered financial assets that lack underlying securities-that simply trade risk-inevitably spread risk throughout the global financial system, and the only defense against collapse would be to impose strict limits on financial engineering and the institutions that trade these securities. In literary texts, the play that causes the signifier to float free of the signified generates limitless opportunities for interpretation; but in financial products, the corresponding play can cause risk to cascade through a global system of interrelated financial institutions, with catastrophic results.

Kevin Brine, who co-authored Finance in America with me, is a veteran of Wall Street-a one-time partner in a major brokerage firm, whose career spanned the decades in which companies like his hired the quants who engineered the products that made a lot of money and nearly broke the system. During the ten years we worked on the book, Kevin and I had numerous disagreements about how to phrase descriptions that touched on the constructed nature of the economic principles and financial instruments he took for granted throughout his career. When we wrote about the creation of national income accounting, for example, I wanted to say that national accountants created "what now counts as the national economy." Kevin wanted to say that they created "the national economy." The difference, of course, is that my wording emphasizes the social labor inherent in maintaining the effect of "the national economy," whereas his wording allows "the national economy" simply to become the natural object most readers imagine it to be. In the end, because we wanted to attract readers who work on Wall Street, as well as economists-not just literary scholars-we most often chose Kevin's phrases. In other words, writing the book, Kevin and I enacted the dispute between economists and literary scholars I have been describing in this article-with the major caveat that I had the chance to persuade him that recognizing the constructed nature of economic and financial concepts and tools could enrich our appreciation of these things. Most people who trade securities for a living, generate and promote economic theories, or advise legislators on economic matters have no incentive to view their tools or theories as social constructs. And even if they do recognize the social nature of their tools, they want to use them to get their jobs done, not admire the fictions they contain. 
This brings me to my final point. Analytic tools are created for specific tasks. The interpretive tools literary scholars can bring to the study of economics and finance are not designed to do the work economists and securities traders perform. This is a major reason economists and financial theorists see little reason to engage in conversations with us. When literary scholars examine economic and financial theories, tools, and objects, we do it for the conversations we are having with each other, not as contributions to solving the problems economists and financial theorists face. The models they use cannot do what our analytic tools can do: models cannot reveal how social construction works, nor can they encourage the play of discriminating interpretation that literary theories promote. What models can do is simplify as a basis for making generalizations. Such generalizations are useful for some kinds of work, just as the literary theorist's fine-grained descriptions are good for other kinds of work. But, as much as literary scholars might like to engage economists in genuine twoway conversations, we need to recognize that, for the most part, there is no single set of tools capable of doing the disparate jobs our disciplines have historically performed. 
1 The article was first given as a keynote lecture at the Norlit Conference in Copenhagen on August 14, 2019.

2 Martha Woodmansee and Mark Osteen, eds., The New Economic Criticism: Studies at the Intersection of Literature and Economics (London: Routledge, 1999).

3 Michael A. Bernstein, A Perilous Progress: Economists and Public Purpose in Twentieth-Century America (Princeton: Princeton University Press, 2004).

4 Philip Mirowski, Never Let a Serious Crisis Go to Waste: How Neoliberalism Survived the Financial Meltdown (London: Verso, 2014); and Philip Mirowski and Dieter Plehwe, eds., The Road from Mont Pèlerin. The Making of the Neoliberal Thought Collective (Cambridge, MA: Harvard University Press, 2009).
5 Simon Kuznets, "National Income" in Readings in the Theory of Income Distribution (1933; reprint, Homewood, IL: Richard D. Irwin, 1946), 8.

6 Fischer Black, Michael C. Jensen and Myron S. Scholes, "The Capital Asset Pricing Model: Some Empirical Tests" in Studies in the Theory of Capital Markets (New York: Praeger Publishers Inc., 1972), 79-121. 